\title{
Comparison and agreement of criteria for the BMI classification of physically active elderly women living in the Backlands, semi-arid Region
}

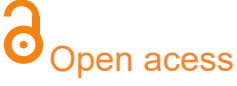

${ }^{1}$ Vale do São Francisco Federal University, Physical Education Department. Av. José de Sá Maniçoba S/N, 56304-917 Centro, Petrolina-PE, Tel.: +55 87- 21016857.

${ }^{2}$ Vale do São Francisco Federal University, Physical Education Department.

\section{${ }^{3}$ Vale do São Francisco Federal University, Physical Education Department. \\ ${ }^{4}$ Vale do São Francisco Federal University, Physical Education Department. \\ Corresponding author:}

Manuscript received: January 2017 Manuscript accepted: November 2017 Version of record online: December 2017

\begin{abstract}
Marcelo de Maio Nascimento ${ }^{1}$, Luiz Gabriel Dantas Pereira ${ }^{2}$, Phillipe Ramon Nogueira Cordeiro ${ }^{3}$, Luciana Márcia Gomes de Araújo ${ }^{4}$
\end{abstract}

\begin{abstract}
Introduction: The study of the nutritional status of the elderly merits attention, since there is no consensus regarding the criteria for the evaluation of the Body Mass Index (BMI) of this population.
\end{abstract}

Objective: The evaluation of the nutritional status of elderly women practicing regular physical exercise, as well as the comparison of the World Health Organization (WHO) and the Lipschitz criteria for the identification of health risks in order to examine their agreement.

Method: A descriptive cross-sectional study was conducted with the participation of 76 elderly women taking part in physical exercise groups in Petrolina-PE. The nutritional status was obtained by the calculation of $\mathrm{BMI}$, according to the WHO and Lipschitz criteria. The Variance analysis (ANOVA) was used to compare the variables, followed by Tukey's post hoc. The Kappa statistic established an agreement between the two BMI criteria and the Spearman coefficient determined a correlation between BMI and waist circumference (WC).

Results: Elderly women aged 60-79 years old were classified as being overweight by $\mathrm{WHO}$ and eutrophic by Lipschitz. Participants 80-89 years old demonstrated eutrophy, according to the Lipschitz criteria, while the WHO criteria diverged for this group between thinness and eutrophy. There was weak agreement between both the criteria, Kappa $(0.232, p=0.002)$ and a strong correlation between BMI and WC $(r=0.722, p<0.001)$.

Conclusion: A divergence between the $\mathrm{WHO}$ and Lipschitz criteria was found. The WHO criteria proved to be more sensitive for identifying overweight and obesity, while the Lipschitz criteria were more sensitive for identifying normal weight and malnutrition. The WC measure was more accurate for detecting health risks, especially in elderly eutrophic women.

Keywords: elderly, BMI, waist circumference, obesity. 


\section{INTRODUCTION}

Overweight, and in particular, obesity, are considered chronic diseases that interact with a range of sicknesses of epidemiological severity ${ }^{1}$. In the human body, the excess of adipose tissue is involved, as it potentializes the development of cardiovascular, osteomuscular, and neoplastic pathologies ${ }^{2,3}$. In the case of elderly individuals, the focus group of this investigation, systematic reviews and meta-analysis studies have demonstrated that there is a relationship between obesity, dementia, and cognitive capacity $^{4,5}$.

Alterations in nutritional state negatively reflect the quality of life (QL) of an elderly individual, and can even result in death ${ }^{2,3}$. Thus, overweight or obese populations are treated as public health issues ${ }^{2,6}$, indicating the need for the development of studies and the perfection of measures which qualify the evaluation of nutritional status. The factors that induce nutritional alterations are found to be related to the genetic characteristics of a person, as well as the cultural aspects of the elderly individual, and the lifestyle adopted. In general, the diagnosis of nutritional state is obtained through the evaluation of nutritional risk, as determined by the Body Mass Index (BMI), which is also known as Quetelet's index ${ }^{7}$.

Studies have highlighted that the use of BMI offers advantages, due to being a low-cost and easily applicable procedure with little variety among intra- and inter-raters ${ }^{7}$. BMI serves as a predictor of morbidity and mortality, and is frequently used for the estimation of the prevalence of obesity in populations ${ }^{2,3,5}$. Investigations developed with representative samples have shown that a significant correlation exists between BMI and other anthropometric indicators of non-visceral fat ${ }^{6,7,8}$, such as subscapular skinfold thickness (SST), triceps skinfold thickness (TST), and the measure of hip circumference (HC), as well as the measure of visceral fat, as evaluated by waist circumference $(\mathrm{WC})^{4}$.

On the other hand, BMI is also known to have certain deficits, in that it is not capable of differentiating lean mass from fat mass ${ }^{7,8}$, nor does it allow for the interpretation of results by sex or age group. It also does not differentiate between ethnic and cultural characteristics ${ }^{9}$. Another

\section{METHODS}

This descriptive cross-sectional study was carried out with a non-probabilistic and intentional sample of 76 individuals of the female sex (68.76 \pm 5.86 years). The participants took part in a PA program offered to elderly residents of Petrolina-PE by the Physical Education course at the Vale do São Francisco Federal University (UNIVASF). The activities practiced included hydrogymnastics, swimming, weight training, general gymnastics, tennis, and Pilates. Physical exercise (PE) took place two times a week, for sessions of 60 minutes. The criteria adopted for inclusion in the study were a minimum age of 60 years, participation in the activities for a minimum of three months, and no presentation of any muscular, articular, or bone lesions during the evaluation period. Those that did not reach a $75 \%$ attendance rate for the physical activities during the execution period of the problematic issue is the determination of nutritional state with the BMI cut-off points. Thus, depending on the criteria adopted, the elderly individual will be classified in one category or another, which may or may not indicate a health risk ${ }^{10}$, due to either obesity or malnutrition.

In light of these issues, waist circumference (WC) is referenced as a more efficient measure than BMI for the prediction of health risks related to obesity ${ }^{11}$. This is due to the fact that, in recent decades, the concentration of fat in the abdominal region has been strongly related to the risk of metabolic diseases in the population. In the case of elderly individuals, the accumulation of fat in the waist region is common, due to the combination of sedentariness and a set of alterations in metabolism originating from the process of human aging itself $\mathrm{f}^{1,2,4}$. Thus, the evaluation of WC has been shown to be an important anthropometric measure, with evidence that its association with BMI is capable of better preventing health risks than BMI alone ${ }^{4,6}$.

The criteria that are used most for the analysis of BMI of the elderly population are those proposed by the World Health Organization (WHO) ${ }^{2}$ and by Lipschitz ${ }^{12}$. The WHO evaluation is used more frequently, but comparatively presents limitations as it does not account for alterations in human development. The Lipschitz criterion considers transformations in the aging process which interfere directly in the calculation of BMI, such as the decrease of total body water, bone mineral density (BMD), the reduction of fat-free mass (FFM), and the increase of body fat $(\mathrm{BF})$. Furthermore, considering that physical activity (PA) benefits the metabolism by slowing the set of transformations caused by the aging process ${ }^{13}$, studies that evaluated the BMI of elderly individuals regularly practicing physical exercise (PE) still have not reached a consensus regarding the best measure for testing the nutritional status of this population.

Therefore, the objective of the present study was to evaluate the nutritional status and the measure of $\mathrm{WC}$ of a group of elderly women regularly practicing physical exercise, and to compare the WHO and Lipschitz criteria for the identification of health risks, in order to examine their agreement.

study and those that did not sign the Informed Consent Form (ICF) were excluded from the study. The study was approved by the Ethics Committee for Research with Human Beings of the Vale do São Francisco Federal University/UNIVASF (CAAE: 44113715.3.0000.5196).

\section{Instruments}

The nutritional evaluation was obtained with Quételet's BMI calculation: body mass $(\mathrm{kg} / \mathrm{m} 2) /$ (height) 2 . Body mass was determined by a digital scale - WISO with $0.1 \mathrm{~kg}$ of resolution and a maximum capacity of 150 $\mathrm{kg}$, appropriately calibrated. Height was measured as the distance between the soles of the feet and the highest point on the head (vertex), with the head oriented according to Frankfuert's plane ${ }^{14}$. For the evaluation of the body mass and height indicators, the elderly women remained 
barefoot with a minimum amount of clothing and were positioned standing with their backs to the scale. The adiposity indicator utilized was $\mathrm{WC}$, determined with the use of a flexible and inelastic metric tape placed around the waist. The procedure was carried out on the smallest curvature, without compromising the tissues, and more precisely, between the ribs and the iliac crest. For the cases in which it was impossible to identify the smallest curvature, the evaluation was carried out $2 \mathrm{~cm}$ above the umbilical scar.

Two dependent variables for establishing the classification of nutritional status were addressed, representing the $\mathrm{WHO}^{2}$ and Lipschitz ${ }^{12}$ evaluations, according to the following criteria. The WHO criteria were: underweight $(\mathrm{BMI}<18.5 \mathrm{~kg} / \mathrm{m} 2)$, eutrophy $\left(\mathrm{BMI} 18.5 \mathrm{~kg} / \mathrm{m}^{2}-24.9 \mathrm{~kg} / \mathrm{m}^{2}\right)$, overweight (BMI $25-$ $29.9 \mathrm{~kg} / \mathrm{m} 2$ ), class I obesity (BMI $30 \mathrm{~kg} / \mathrm{m} 2-34.9 \mathrm{~kg} / \mathrm{m}^{2}$ ), class II obesity (BMI $35 \mathrm{~kg} / \mathrm{m} 2-39.9 \mathrm{~kg} / \mathrm{m}^{2}$ ), and class III obesity (BMI $40 \geq \mathrm{kg} / \mathrm{m}^{2}$ ). The Lipschitz criteria were: underweight $\left(\mathrm{BMI}<22 \mathrm{~kg} / \mathrm{m}^{2}\right)$, eutrophy (BMI $22 \mathrm{~kg} / \mathrm{m}^{2}$ $\left.27 \mathrm{~kg} / \mathrm{m}^{2}\right)$ and excess weight $\left(\mathrm{BMI}>27 \mathrm{~kg} / \mathrm{m}^{2}\right)$. The criteria utilized for indicating the risk of metabolic complications

\section{RESULTS}

Among the 76 women who participated in the present study, $41(53.9 \%)$ were 60-69 years old, 31 $(42.2 \%)$ were $70-79$ years old, and $3(3.9 \%)$ were 80 89 years old. Table 1 presents the mean results for the principal variables categorized by age groups. Significant differences were observed among the age groups $(p<0.001)$. Decreases in body mass and height with the increase in age were observed, and a significant difference in women for variable visceral fat were those proposed by $\mathrm{WHO}^{2}$ : $\mathrm{WC}>80 \mathrm{~cm}$ for an increased risk and $\mathrm{WC}>88 \mathrm{~cm}$ for a substantially increased risk.

\section{Statistical analysis}

The results were presented via a descriptive analysis using central tendencies (mean, standard deviation, and frequencies). The test for the distribution of data was verified by the Kolmogorov-Smirnov normality test. The Variance Analysis (ANOVA) of an entry was utilized for the comparison of the studied variables, followed by Tukey's post hoc. The legitimacy test of the BMI results was calculated with Cohen's kappa coefficient: values close to 1.0 indicate excellent results, thus revealing the gold standard. For the association between BMI and AC, Spearmen's correlation coefficient was applied. The data were processed with the Statistical Package for the Social Sciences (SPSS) software, version 19.0. The MedCalc program, version 15.2, was utilized for the presentation of graphics. The level of significance adopted was $p<0.050$.

was found for height when comparing the age groups of 60-69 years and $70-79$ years $(p \leq 0.050)$. Considering BMI, elderly women between 60-79 years of age displayed practically identical averages, while individuals between 80-89 years of age displayed inferior values $(\mathrm{p} \geq 0.050)$. The evaluation of visceral fat demonstrated an increased risk for metabolic complications $(\mathrm{WC}>88 \mathrm{~cm}$ ) in all age groups, with significant differences $(\mathrm{p} \leq 0.050)$.

Table 1: Characteristics of the evaluated population, according to age groups, with values expressed by the mean and standard deviation.

\begin{tabular}{lcccc}
\hline Variables & $\mathbf{6 0 - 6 9}$ years & $\mathbf{7 0 - 7 9}$ years & $\mathbf{> 8 0}$ years & $\mathbf{p}$ \\
\hline Age $($ years $)$ & $64.17 \pm 2.52^{\mathrm{a}, \mathrm{b}}$ & $73.38 \pm 2.61^{\mathrm{a}, \mathrm{c}}$ & $82.33 \pm 2.08^{\mathrm{b}, \mathrm{c}}$ & $<0.001$ \\
Mass $(\mathrm{Kg})$ & $67.25 \pm 9.01$ & $65.15 \pm 13.27$ & $59.50 \pm, 2.78$ & 0.413 \\
Height $(\mathrm{m})$ & $1.55 \pm 0.06^{\mathrm{a}}$ & $1.52 \pm 0.06^{\mathrm{a}}$ & $1.54 \pm 0.04$ & 0.109 \\
BMI $\left(\mathrm{kg} / \mathrm{m}^{2}\right)$ & $27.85 \pm 4.09$ & $27.89 \pm 4.91$ & $24.98 \pm 0.79$ & 0.541 \\
WC $(\mathrm{cm})$ & $88.26 \pm 9.93^{\mathrm{a}}$ & $88.43 \pm 12.17^{\mathrm{c}}$ & $89.00 \pm 9.84^{\mathrm{a}, \mathrm{c}}$ & 0.993 \\
\hline
\end{tabular}

Legend: $\mathrm{SD}=$ standard deviation; $\mathrm{kg}=$ kilogram; $\mathrm{m}^{2}=$ square meters; $\mathrm{WC}=$ waist circumference; $\mathrm{cm}=$ centimeters; $a, b, c=p \leq 0.050$.

Source: Author (2016)

With the use of Cohen's kappa coefficient, a weak level of agreement was verified between the indices designated by the WHO and Lipschitz criteria $(0.232$; $\mathrm{p}=0.002$ ). This finding became more evident after the comparative analysis of the nutritional state classifications by age group (Table 2). In accordance with the WHO criteria, a state of thinness was identified in 3/76 elderly women, while the Lipschitz criteria classified 7/76 women as thin. For normal weight, the WHO criteria identified 16/76 women with normal weight, while the Lipschitz criteria classified 30/76 elderly women with normal weight. Considering that the Lipschitz classification does not distinguish between the categories of overweight and obese, but the WHO criteria distinguishes both, individuals were grouped according to the WHO classification: 39/76 elderly women were classified as overweight, 12/76 were classified with class I obesity, and 6/76 were classified with class II obesity. Therefore, the evaluation of health risks with the WHO criteria identified 57/76 elderly women at risk, while the Lipschitz criteria detected 39/76 elderly women at risk. 
Table 2: Prevalence of nutritional status, WHO and Lipschitz criteria

\begin{tabular}{lccc}
\hline Groups (years) & Underweight & Eutrophy & Overweight/Obesity \\
\hline WHO & $\mathbf{n ~ ( \% )}$ & $\mathbf{n}(\%)$ & $\mathbf{n}(\%)$ \\
$60-69$ & & & \\
$70-79$ & -------- & $8(19.5)$ & $33(80.5)$ \\
$>80$ & $1(3.1)$ & $7(21.9)$ & $24(75.0)$ \\
Total & $2(66.7)$ & $1(33.3)$ & ------- \\
Lipschitz & 3 & 16 & 57 \\
$60-69$ & & & $23(56.1)$ \\
$70-79$ & $4(9.8)$ & $14(34.1)$ & $16(50.0)$ \\
$>80$ & $3(9.4)$ & $13(40.6)$ & -------- \\
Total & -------- & $3(100.0)$ & 39 \\
\hline
\end{tabular}

Source: Author (2016).

Figure 1 compares the mean values for WC with nutritional status, discriminating between the results according to the WHO and Lipschitz criteria. Considering the value $\mathrm{WC} \geq 80 \mathrm{~cm}$ as an indicator of visceral fat for health risks and the measure of $\mathrm{WC}>88 \mathrm{~cm}$ as an indicator of increased risks, it is observed that the elderly women classified as underweight did not display health risks. However, those qualified as normal weight by both sets of criteria displayed values of $\mathrm{WC} \geq 80 \mathrm{~cm}$, warning of health risks. As expected, elderly women who qualified as

Figure 1: Average values of WC $(\mathrm{cm})$, compared with the BMI $\left(\mathrm{kg} / \mathrm{m}^{2}\right)$, according to the cut-off points of the WHO and Lipschitz criteria.

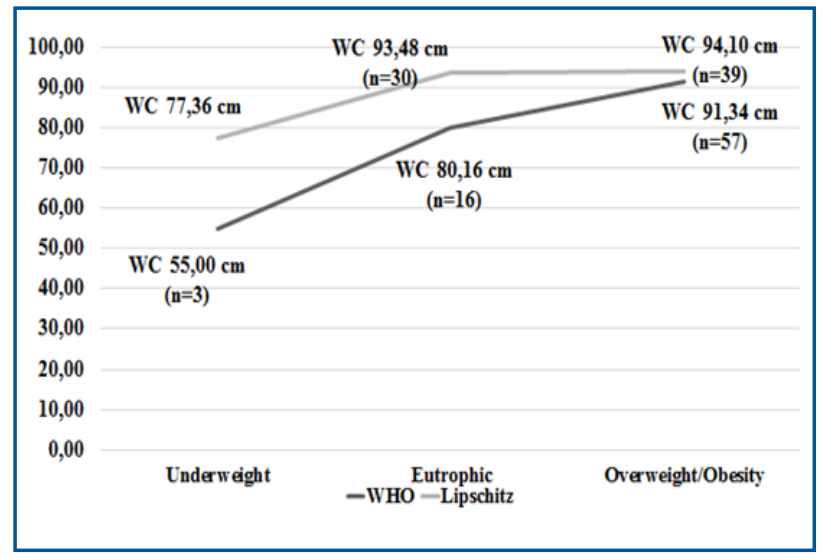

\section{DISCUSSION}

The population analyzed was composed of women, a characteristic of the physical activity program where the investigation was conducted. The predominance of feminization in aging and in physical activity programs at the national level has been emphasized by previous studies $^{15,16}$, highlighting the commitment of elderly women to health prevention.

Considering the stratification by age group, participants aged 60-69 years old and 70-79 years old made up $96.1 \%$ of the evaluated population, and the rest were 80-89 years old. In the present study, before the overweight and obese demonstrated mean values for WC greater than $90 \mathrm{~cm}$, warning of increased health risks.

With the objective of verifying the agreement between BMI and WC measures, the level of correlation between the variables was determined. The statistical analysis indicated a strong relation $(\mathrm{r}=0.722, \mathrm{p}<0.001)$, demonstrating that the measures are complimentary to the prediction of health risks for physically active elderly women (Figure 2):

Figure 2: Correlation between the Body Mass Index and Waist Circumference.

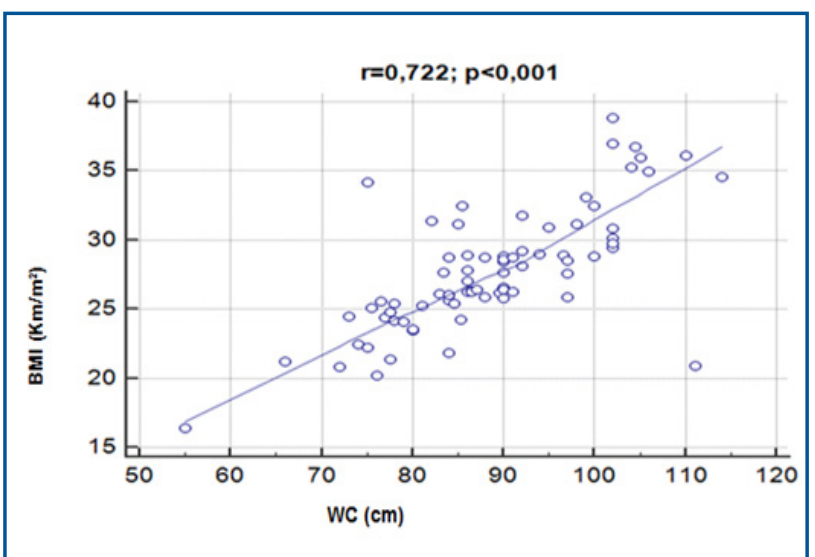

comparison of the BMI judgments, the WHO cut-off points referring to overweight, class I obesity, and class II obesity were aggregated. Thus, comparatively, the WHO criteria classified $73.5 \%$ of the elderly women, primarily, with nutritional states of overweight and obesity. On the other hand, the Lipschitz criteria classified $49.4 \%$ of participants with excess weight. Therefore, comparatively, the Lipschitz criteria qualified 50\% more of the elderly women as having normal weight than the WHO criteria. Nevertheless, the finding invites doubts regarding the existence of false-positive results among those elderly 
women classified as overweight by the WHO criteria.

Regarding the groups of women aged 80-89 years, divergence between the judgments was also observed, such that the Lipschitz criteria qualified $100 \%$ of the participants above 80 years of age as eutrophic. However, the WHO criteria indicated $66.7 \%$ of participants in a state of thinness and $33.3 \%$ as eutrophic. This finding corroborated the findings of previous studies that described the existence of a relative reduction of BMI with an increase in age. This is due to the decrease of lean mass, an increase in fat mass, and alterations in the standard distribution of body fat $t^{2,17}$, common after reaching 70 years of age . $^{8}$

According to the specialized literature, comparatively women present greater subcutaneous fat gain than men17. This merits attention principally in the elderly population, due to elevated levels of arterial hypertension, that when associated with obesity can increase the risk of myocardial infarction and cerebrovascular accident by 2 to 4 times $^{17,18}$. In a study carried out in the Northeast region of Brazil ${ }^{19}$ with 236 women between 60-80 years of age, it was verified that obesity accompanied by co-morbidities, such as diabetes mellitus, arterial hypertension, cardiovascular, renal, and osteoarticular diseases, favors the onset of metabolic syndrome. In light of this, the regular practice of PE can act as a regulatory factor and/or protector of elderly health ${ }^{13}$.

Overweight and obese conditions also directly reflect the functional state of the individual, impeding $\mathrm{him} / \mathrm{her}$ from carrying out daily life activities (DLA) independently ${ }^{2,5,6}$. In an investigation developed with 3,496 elderly non-institutionalized individuals in the Portuguese population ${ }^{13}$ over 65 years of age, it was observed that physical aptitude can determine the functionality and independence of the elderly individual. As a provision, it is suggested that these individuals adopt a level of aerobic physical activity of 150 minutes weekly, along with muscular strengthening exercises. According to the authors, the measure is capable of preventing or mitigating the negative implications of overweight or obese conditions in the human organism17. Thus, it can be said that the elderly women aged 60-69 years and 70-79 years evaluated in the present study, even while exhibiting an overweight or obese condition, benefited from the regular practice of PA as a protective factor for their health. In addition to their participation twice a week in the PA program activities, they experienced an additional caloric expenditure during daily life activities (DLAs).

The statistical analysis indicated a low agreement between the WHO and Lipschitz criteria for establishing the nutritional state of elderly women regularly practicing PE. With this perspective, it was observed that the cut-off points in the Lipschitz criteria presented greater sensitivity for the classification of an underweight condition. Souza et $a l^{8}$, upon evaluating 131 elderly individuals in the city of Porto Alegre-RS, found two elderly individuals (1.5\%) with an underweight condition according to the WHO criteria and, 21 individuals (16\%) with an underweight condition according to the cut-off points provided by the Lipschitz criteria. In accordance with these results, in the present study the WHO criteria indicated three elderly women $(3.8 \%)$ in a state of thinness, while $7(9.2 \%)$ were classified in a state of thinness by the Lipschitz measure. The findings confirmed the specialized literature that attributed a greater efficacy in determining an underweight condition to the Lipschitz criteria ${ }^{8}$. In another investigation carried out with 106 elderly women in the city of Recife-PE ${ }^{20}$, the WHO criteria classified $1.9 \%$ of the participants with a condition of malnutrition, while the Lipschitz criteria indicated $12.3 \%$.

It is important to highlight that, when dealing with the nutritional state of the elderly population, one should be aware that individuals $\geq 70$ years of age are more predisposed to diseases, thus characterizing a fragile population ${ }^{20}$. This means that the diagnosis of an underweight condition also demands attention, since the elderly are vulnerable to a state of malnutrition. Furthermore, the nutritional ingestion of this group is a complex procedure, making it impossible to define with precision their nutritional needs. Thus, there are restrictions regarding dietary methods applied to the elderly ${ }^{8,21}$.

In relation to normal weight, a prevalence of $38 \%$ was verified when applying the Lipschitz criteria and of $21.5 \%$ when applying the WHO criteria. In a study carried out in Recife-PE ${ }^{20}$, also with elderly women, the Lipschitz measure qualified $40.6 \%$ of individuals with normal weight, while the WHO measure indicated $33 \%$. Comparatively, regarding overweight and obese conditions, the WHO criteria were more sensitive than the Lipschitz criteria for the health risk exam. This low level of agreement between the two sets of criteria was demonstrated by a weak Kappa coefficient. In accordance with Souza et al. ${ }^{8}$, the evaluation of the nutritional state of the elderly is problematic because specific cut-off points for this population do not exist. As such, the values utilized are the same ones applied to youth and adult individuals ${ }^{22}$.

It is assumed that, for the evaluated population, the cut-off points of the WHO and Lipschitz criteria can be employed, albeit with caution, such that the researcher, with a foundation in the specialized literature, is responsible for determining whether the measure obtained is valid or not. It is known that the use of BMI is controversial. Stevens et $a l .{ }^{23}$, upon developing a comparative ethnic study regarding the nutritional state of Afro-American and white women, highlighted that the choice of values that determine the cut-off points could be related to political issues. Still, the results of the BMI exam are important, since the data function as a parameter for approval of parts of the governmental budget, in addition to integrating strategies for promoting health ${ }^{6}$.

An important finding in the present study is the confirmation of health risks through the use of the visceral fat (WC) evaluation. This measure permitted the detection of hidden health risks in elderly women classified with a normal nutritional state by both the WHO and Lipschitz criteria (Figure 1). The finding corroborated the findings of previous studies that warned against the limitation of BMI for the exact determination of the state of health, especially of the elderly ${ }^{7,8}$. This result serves as a warning, since eutrophic individuals with elevated levels of WC belong to a group with a combination of visceral adiposity and a 
loss of lean mass, those referred to as dysmetabolically thin. These individuals have been found to be predisposed to developing diseases analogous to obese individuals, such as, for example, the increase of cholesterol levels, coronary diseases, diabetes, and hypertension, which merit special attention and care.

In an investigation carried out with 14,934 individuals, Janssen et.al. ${ }^{24}$ analyzed BMI and WC measures in order to estimate the relationship between nutritional disturbances and the prevalence of diseases, as well as the relationship of these measures with risk factors for diseases. The results demonstrated that for individuals with normal weight, those with an overweight condition, and those with obesity all presented an analogous health risk. Given this finding, the authors concluded that WC is the more appropriate measure for the indication of health risks. In the present study, a significant and strong correlation $(\mathrm{r}=0.722 ; \mathrm{p}<0.001)$ between $\mathrm{WC}$ and BMI was found. This result confirmed that, for the evaluated population, health risks can be verified by the visceral fat exam. The finding does not disqualify the use of BMI as a predictive measure for health risks, and BMI remains a useful tool for the evaluation of the state of health.

Another interesting finding in the present study was that elderly women aged 80-89, classified with a normal nutritional state by both sets of criteria, demonstrated an increased risk for metabolic complications (WC $>88$ $\mathrm{cm}, \mathrm{p} \leq 0.050$ ). The case supports the results of previous investigations that qualified the $\mathrm{WC}$ measure as capable of better predicting the risk of cardiometabolic diseases ${ }^{25}$, including those in hidden situations ${ }^{15}$.

A possible limitation of this study that should be considered is the exclusion of cutaneous fold measures, which could expand the discussion of the results. It is suggested that future studies be conducted comparing BMI criteria and examining their agreement with $\mathrm{WC}$, principally with elderly individuals that regularly practice physical exercises, such that the results can complement the findings of this investigation.

\section{CONCLUSION}

In conclusion, a low level of agreement between the WHO and Lipschitz criteria for the evaluation of the nutritional state of elderly women regularly practicing physical exercise was found. For the age group of individuals 60-70 years old, the WHO criteria classified the participants mainly with overweight and obese conditions, while the Lipschitz criteria were more sensitive for determining normal weight and malnutrition. The criteria also were not unanimous for the evaluation of individuals aged $80-89$, qualified as normal weight or as thin. The measure of visceral fat was shown to be more specific than BMI for the identification of an increased risk for metabolic complications, especially for elderly women classified by both sets of criteria as eutrophic.

\section{Acknowledgements}

To the Grant MEC-PROEXT/2015-2016.

\section{REFERENCES}

1. Leal Neto JS, Barbosa AR, Meneghini V. Diseases and chronic health conditions, multimorbidity and body mass index in older adults. Rev Bras Cineantropom Desempenho Hum. 2016;18(5):509-19. DOI: http://dx.doi.org/10.5007/1980-0037.2016v18n5p509

2. World Health Organization (WHO). Obesity: preventing and managing the global epidemic. Geneva: WHO; 2000.

3. World Health Organization (WHO). Physical status: The use and interpretation of anthropometry. Report of a WHO expert committee. Geneva: WHO; 1995.

4. Flegal KM, Kit BK, Orpana H, Graubard BI. Association of all-causemortality with overweight and obesity using standard bodymass index categories a systematic review andmeta-analysis. Jama. 2013;309(1):71-82. DOI: http://dx.doi.org/10.1001/jama.2012.113905

5. Aslan AK, Starr JM, Pattie A, Deary I. Cognitive consequences of overweight and obesity in the ninth decade of life? Age Ageing. 2014;44(1):59-65. DOI: http://dx.doi.org/10.1093/ageing/afu108

6. Konig HH, Lehnert T, Brenner H, Schottker B, Quinzler R, Haefeli WE, et al. Health service use and costs associated with excess weight in older adults in Germany. Age Ageing. 2015;44(4):616-623. DOI: http://dx.doi.org/10.1093/ageing/afu120

7. Anjos LA. Indice de massa corporal (massa corporal.estatura-2) como indicador do estado nutricional de adultos: revisão da literatura. Rev Saude Publica. 1992;26(6):431-6. DOI: http://dx.doi.org/10.1590/S0034-89101992000600009

8. Souza R, Fraga JS, Gottschall CBA, Busnello FM, Rabito El. Avaliação antropométrica em idosos: estimativas de peso e altura e concordância entre classificações de IMC. Rev Bras Geriatr Gerontol. 2013;16(1):81-90. DOI: http://dx.doi.org/10.1590/S1809-98232013000100009

9. Flegal KM, Carroll MD, Kit BK, Ogden CL. Prevalence of obesity and trends in the distribution of body mass index among US adultsc, 1999-2010. Jama. 2012;307(5):491-7. DOI: http://dx.doi.org/10.1001/jama.2012.39 
10. Westphal P, Ferreira C, Adamczeski M, Camargo L, Santos R, Massaneiro AC, et al. Relação entre Índice de Massa Corporal de Quételet e o de Trefethen. Rev Centro Pesq Avançadas Qual Vida. 2016;8(3):1-6.

11. Chinedu SN, Ogunlana OO, Azuh DE, Iweala EEJ, Afalobi IS, Uhuegibu CC, et al. Correlation between body mass index and waist circumference in nigerian adults: implication as indicators of health status. J Public health Res. 2013;2(2):e16. DOI: http://dx.doi.org/10.4081/jphr.2013.e16

12. Lipschitz DA. Screening for nutritional status in the elderly. Prim Care. 1994;21(1):55-67.

13. Sardinha LB, Cyrino ES, Santos LD, Ekelund U, Santos DA. Fitness but not weight status is associated with projected physical independence in older adults. Age (Dordr). 2016;38(3):54. DOI: http://dx.doi.org/10.1007/s11357-016-9911-4

14. Petroski EL. Antropometria: técnicas e padronizações. Várzea Paulista: Fontoura, 2011.

15. Almeida AV, Mafra SCT, Da Silva EP, Kanso S. A feminização da velhice: em foco as características socioeconômicas, pessoais e familiares das idosas e o risco social. Textos Context. 2015;14(1):115-31. DOI: http://dx.doi.org/10.15448/1677-9509.2015.1.19830

16. Salin MS, Mazo GZ, Cardoso ASA, Garcia GS. Atividade Física para idosos: diretrizes para implantação de programas e ações. Rev Bras Geriatr Gerontol. 2011;14(2):197-208. DOI: http://dx.doi.org/10.1590/S1809-98232011000200002

17. Vilaça KHC, Carneiro JAO, Pessanha FPAS, Lima NKC, Ferriolli E, Moriguti JC. Estudo comparativo da composição corporal de idosas fisicamente ativas pelos métodos DXA e antropométrico. Rev Bras Ciênc Mov. 2012;20(3):5-13.

18. Diniz KO, Rocha SV, Oliveira ACC. Anthropometric indicators of obesity such as predictors of high blood pressure in the elderly. Rev Bras Cineantropom Desempenho Hum. 2017;19(1):31-9. DOI: http://dx.doi.org/10.5007/1980-0037.2017v19n1p31

19. Rocha FL, Melo RLP. Menezes TN. Fatores associados à síndrome metabólica em idosos do interior do Nordeste brasileiro. Rev Bras Geriatr Gerontol. 2016;19(6):978-86. DOI: http://dx.doi.org/10.1590/1981-22562016019.160046

20. Amado TCF, Arruda IKG, Ferreira RAR. Aspectos alimentares, nutricionais e de saúde de idosas atendidas no Núcleo de Atenção ao Idoso - NAI, Recife/2005. Arch Latinoam Nutr. 2007;57(4):366-72.

21. Arnau A, Espaulella J, Serrarols M, Canudas J, Formiga F, Ferrer M. Risk factors for functional decline in a population aged 75 years and older without total dependence: A one-year follow-up. Arch Gerontol Geriatr. 2016;65:239-47. DOI: http://dx.doi.org/10.1016/j.archger.2016.04.002

22. Fisberg RM, Marchioni DML, Castro MA, Verly Junior E, Araújo MC, Bezerra IN, et al. Ingestão inadequada de nutrientes na população de idosos do Brasil: Inquérito Nacional de Alimentação 2008-2009. Rev Saude Publica. 2013;47(1 Supl.):222s-30. DOI: http://dx.doi.org/10.1590/S0034-89102013000200008

23. Sass A, Marcon SS. Comparação de medidas antropométricas de idosos residentes em área urbana no sul do Brasil, segundo sexo e faixa etária. Rev Bras Geriatr Gerontol. 2015;18(2):261-72. DOI: http://dx.doi.org/10.1590/1809-9823.2015.13048

24. Janssen I, Katzmarzyk PT, Ross R. Waist circumference and not body mass index explains obesityrelated health risk. Am J Clin Nutr. 2004;79(3):379-84.

25. Bozeman SR, Hoaglin DC, Burton TM, Pashos CL, Ben-Joseph RH, Hollenbeak CS. Predicting waist circumference from body mass index. BMC Med Res Methodol. 2012;12:115. DOI: http://dx.doi.org/10.1186/1471-2288-12-115 


\section{Resumo}

Introdução: O estudo do estado nutricional de idosos merece atenção, visto que não existe um consenso sobre os critérios ideias à avaliação do Índice de Massa Corporal (IMC) dessa população.

Objetivo: Avaliar o estado nutricional de idosas praticantes regulares de exercícios físicos, bem como comparar os critérios da Organização Mundial de Saúde (OMS) e de Lipschitz à identificação do risco de saúde e examinar sua concordância.

Método: Estudo transversal analítico descritivo, realizado com 76 idosas integrantes de grupos de exercícios físicos, em Petrolina-PE. O estado nutricional foi obtido pelo cálculo do IMC, conforme os critérios da OMS e Lipschitz. Utilizou-se a análise de Variância (ANOVA) para comparação das variáveis, seguida pelo post hoc de Tukey. A estatística de Kappa estabeleceu a concordância entre os critérios do IMC, o coeficiente de Spearman determinou a correlação entre o IMC e a medida da circunferência abdominal (CA).

Resultados: Idosas entre 60-79 anos foram classificadas, sobretudo, com excesso de peso pela OMS e eutróficas por Lipschitz. Octogenárias demonstraram eutrofia segundo o critério de Lipschitz, a OMS divergiu para este grupo entre magreza e eutrofia. Verificou-se concordância fraca entre ambos os critérios, Kappa $(0,232, p=0,002)$ e forte correlação entre o IMC e a CA $(r=0,722, p<0,001)$.

Conclusão: Existiu divergência entre os critérios da OMS e Lipschitz. A OMS se mostrou mais sensíveis para identificar sobrepeso e obesidade e Lipschitz o peso normal e a desnutrição. A medida da CA foi mais competente para detectar o risco de saúde, principalmente, em idosas eutróficas

Palavras-chave: idoso, IMC, circunferência abdominal, obesidade.

- The authors (2017), this article is distributed under the terms of the Creative Commons Attribution 4.0 International License (http://creativecommons.org/licenses/by/4.0/), which permits unrestricted use, distribution, and reproduction in any medium, provided you give appropriate credit to the original author(s) and the source, provide a link to the Creative Commons license, and indicate if changes were made. The Creative Commons Public Domain Dedication waiver (http://creativecommons.org/publicdomain/ zero/1.0/) applies to the data made available in this article, unless otherwise stated. 